\title{
Effect of Microwave Disinfection on Physical and Mechanical Properties of Acrylic Resins
}

\author{
Rafael Leonardo Xediek CONSANI ${ }^{1}$ \\ Erica Brenoe VIEIRA ${ }^{2}$ \\ Marcelo Ferraz MESQUITA ${ }^{1}$ \\ Wilson Batista MENDES ${ }^{3}$ \\ João Neudenir ARIOLI-FILHO ${ }^{4}$ \\ ${ }^{1}$ Department of Prosthodontics and Periodontics, Dental School of Piracicaba, \\ State University of Campinas, Piracicaba, SP, Brazil \\ ${ }^{2}$ Dental School of Piracicaba, State University of Campinas, Piracicaba, SP, Brazil \\ ${ }^{3}$ Department of Clinics, Dental School, Itaúna University, MG, Brazil \\ ${ }^{4}$ Department of Dental Materials and Prosthodontics, Dental School of Araraquara, \\ São Paulo State University, Araraquara, SP, Brazil
}

\begin{abstract}
This study evaluated the effect of microwave energy on the hardness, impact strength and flexural strength of the Clássico, Onda-Cryl and QC-20 acrylic resins. Aluminum die were embedded in metallic or plastic flasks with type III dental stone, in accordance with the traditional packing technique. A mixing powder/liquid ratio was used according to the manufacturer's instructions. After polymerization in water batch at $74^{\circ} \mathrm{C}$ for $9 \mathrm{~h}$, boiling water for $20 \mathrm{~min}$ or microwave energy at $900 \mathrm{~W}$ for $10 \mathrm{~min}$, the specimens were deflasked after flask cooling at room temperature, and submitted to finishing. Specimens non-disinfected and disinfected by microwave irradiation were submitted to hardness, impact and flexural strength tests. Each specimen was immersed in distilled water and disinfected in a microwave oven calibrated to $650 \mathrm{~W}$ for $3 \mathrm{~min}$. Knoop hardness test was performed with $25 \mathrm{~g}$ load for $10 \mathrm{~s}$, impact test was carried out using the Charpy system with $40 \mathrm{kpcm}$, and 3-point bending test with a crosshead speed of $0.5 \mathrm{~mm} / \mathrm{min}$ until fracture. Data were submitted to statistical analysis by ANOVA and Tukey's test $(\alpha=0.05)$. Disinfection by microwave energy decreased the hardness of Clássico and Onda-Cryl acrylic resins, but no effect was observed on the impact and flexural strength of all tested resins.
\end{abstract}

Key Words: hardness, impact, flexural strength, acrylic resin, microwave disinfection.

\section{INTRODUCTION}

Treatments in dental clinics use instruments and prosthetic materials that should be properly disinfected or sterilized to avoid cross-contamination among dentists, patients, assistants and technicians in the dental prosthetic laboratory. In addition to cross-contamination caused by the patients, prostheses can be contaminated by microorganisms during the different stages of fabrication. In order to eliminate or reduce the crosscontamination, the prostheses should be disinfected with chemical solutions. Prosthetic materials sent from the dental clinics to the dental laboratories are contaminated by pathogenic bacteria, which could be trans- ferred to the technicians by means of direct contact or during the finishing and polishing procedures (1).

A previous study showed that microorganisms found in pumice slurry were originated from contaminated prosthetic pieces, which were polished without prior disinfection or cleanness. Unde these conditions, these pathogens can be transferred to other prostheses and prosthetic pieces during laboratory procedures (2).

Chemical disinfection has been suggested with the aim to avoid the cross-contamination due to dissemination of pathogenic agents, using glutaraldehyde, sodium hypochlorite, iodoform, chlorine dioxide or alcohol solutions (3). However, chemical disinfection may present disadvantages like denture staining and 
patient's oral tissue reactions $(4,5)$.

In order to overcome the disadvantages of chemical disinfection, the use of microwave energy has been suggested in Dentistry as a simple alternative to prosthesis disinfection. It is considered a an easily accessible, simple to perform and low-cost method. Originally used for polymerization of thermally activated acrylic resins, microwave energy irradiation by conventional domestic oven for disinfection of soft lining and acrylic resin immersed in water has been proven effective for sterilization of the specimens contaminated by fungus (6).

Considering the probability of the acrylic resin denture base to be contaminated both internally and externally, microwave energy has been pointed out as an ideal disinfection method (4). Acrylic resin disinfection by microwave energy has shown satisfactory results concerning the method effectiveness. A previous study (7) showed that the hardness, dimensional changes and flexural strength of the tested acrylic resin were not significantly altered when chemical and microwave energy disinfection procedures were compared.

Few studies have been developed to verify whether microwave disinfection would change the physical and mechanical properties of acrylic resins. Disinfection procedures should not cause dimensional changes or distortion of the acrylic resin denture base, otherwise the stability, retention and durability of the complete dentures can be compromised (8).

The purpose of this study was to evaluate the effect of microwave disinfection on the hardness, impact strength and flexural strength of Clássico (long cycle), QC-20 (short cycle) and Onda-Cryl (microwave energy) thermally activated acrylic resins. The tested null hypothesis was that microwave disinfection adversely affects these mechanical properties of the evaluated acrylic resins.

\section{MATERIAL AND METHODS}

The following acrylic resins were used for specimen fabricatrion: Clássico (Clássico Artigos Odontológicos Ltda.; São Paulo, SP, Brazil; Powder: polymethyl metacrylate; Liquid: methyl methacrylate MMA); QC-20 (Dentsply Ind. e Com. Ltda., Petropólis, RJ, Brazil; Powder: co-polymer of methyl/n butyl metacrylate, benzoile peroxide and mineral pigments; Liquid: MMA, etyleneglycol, dimetacrylate, hydroquinone, tertinolene, and n,n-dimetyl p-toluidine); Onda-Cryl (Clássico Artigos Odontológicos Ltda.; Powder: MMA and EADPB co-polymers and benzoile peroxide; Liquid: MMA monomer, topanol, etylene-glycoldimetacrylate.

Aluminum rectangular pattern dies $(65.0 \times 12.0$ x $3.5 \mathrm{~mm}$ ) were embedded in metallic (Safrany; J. Safrany Metallurgy, São Paulo, SP, Brazil) or plastic (GC; GC Dental Products, São Paulo, SP, Brazil) flasks with type III dental stone (Herodent; Vigodent, Petrópolis, RJ, Brazil), prepared at a ratio of $30 \mathrm{~mL}$ water to $100 \mathrm{~g}$ powder, according to the manufacturer's instructions. After pattern dies inclusion, the metallic and plastic flasks were pressed in a bench press under $850 \mathrm{kgf}$ load for $1 \mathrm{~h}$. After this period, the aluminum pattern dies were deflasked and the reproduction accuracy was verified in the stone molds.

Thirty specimens were made for each acrylic resin, being 10 specimens for each mechanical test. Five specimens were tested before microwave disinfection and served as controls, and 5 were tested after microwaving. Powder-to-liquid ratio and mixing procedures were as per manufacturer's instructions and according to each protocol. The following three groups $(n=10)$ were formed: Group 1: Clássico pressing, polymerization in water bath at $74^{\circ} \mathrm{C}$ for $9 \mathrm{~h}$ (Termotron; Termotron Laboratory Products, Piracicaba, SP, Brazil) and deflasking after bench cooling at room temperature; Group 2: QC-20 pressing, polymerization in boiling water in steam press (Termotron) for $20 \mathrm{~min}$ and deflasking after bench cooling at room temperature; Group 3: Onda-Cryl pressing, polymerization by microwave energy in domestic oven (Continental; Manaus, AM, Brazil) with $900 \mathrm{~W}$ potency ( $3 \mathrm{~min}$ at $40 \%$ power; $4 \mathrm{~min}$ at $0 \%$ power; and $3 \mathrm{~min}$ at $90 \%$ power), and deflasking after bench cooling at room temperature.

Clássico was prepared with a monomer:polymer ratio of $1: 3$ by volume, corresponding to $37.5 \mathrm{~g}$ powder to $15 \mathrm{~mL}$ liquid. A ratio of $23 \mathrm{~g}$ powder to $10 \mathrm{~mL}$ liquid was used for QC-20. The prepared dough was packed in the doughlike stage in a hydraulic press (Linea $\mathrm{H}$; Linea, São Paulo, SP, Brazil) with a load of $850 \mathrm{kgf}$. A polyethylene sheet was used as a separating medium during the initial flask packing. After, the flask was opened, the polyethylene sheet was removed and the acrylic resin excess was trimmed. In the metallic flask, after final closure had been performed under $1,250 \mathrm{kgf}$ load for $5 \mathrm{~min}$, the flasks were placed in traditional 
spring cramps. The final closure of the plastic flasks was under a load of 1,000 $\mathrm{kgf}$ for $5 \mathrm{~min}$. Before press release, the plastic flasks were tightened by screws.

After deflasking, the specimens were finished using stones for acrylic resin abrasion and sandpaper of decreasing abrasiveness. Pumice slurry was used with white and black brushes and felt tip for the polishing in a bench lathe. After final polishing with flannel wheel and universal paste (Kota Manufacturing Co., São Paulo, SP, Brazil), the specimens presented dimensions of $65.0 \times 10.0 \times 3.3 \mathrm{~mm}$, according to ISO specifications (9). After polishing, all specimens were stored in distilled water at $37^{\circ} \mathrm{C}$ for $24 \mathrm{~h}$.

In each group, 5 specimens were submitted to the hardness, impact strength and flexural strength tests with no microwave disinfection. The remaining 5 specimens were submitted to a microwave disinfection cycle in a domestic microwave oven (Continental) at $650 \mathrm{~W}$ for $3 \mathrm{~min}$ (5). For this procedure, the specimens were immersed individually in $150 \mathrm{~mL}$ of distilled water in a glass container (10).

Knoop hardness was tested in a microhardness tester (Shimadzu HMV-2000; Shimadzu, Tokyo, Japan) calibrated with load of $25 \mathrm{~g}$ for $10 \mathrm{~s}$. Three indentations were made on the surface of each specimen, one in the center and one in each end. The average of the three indentations was considered as the specimen hardness and was expressed as KHN.

Impact strength was tested by the Charpy system (Otto Wolpert Werke, Germany) with $40 \mathrm{kpcm}$ impact load. The impact load obtained in the moment of the specimen failure was converted into impact strength $\left(\mathrm{kgf} / \mathrm{cm}^{2}\right)$ using the following equation: IS=I/LH, where:

Table 1. Knoop hardness means (KHN) and standard deviations for Clássico, QC-20 and Onda-Cryl acrylic resins.

\begin{tabular}{ccc}
\hline Acrylic resin & \multicolumn{2}{c}{ Microwave disinfection } \\
\cline { 2 - 3 } & Non-disinfected & Disinfected \\
\hline Clássico & $14.59 \pm 1.45 \mathrm{a}, \mathrm{A}$ & $10.64 \pm 0.97 \mathrm{a}, \mathrm{B}$ \\
QC-20 & $11.53 \pm 0.67 \mathrm{~b}, \mathrm{~A}$ & $10.46 \pm 1.64 \mathrm{a}, \mathrm{A}$ \\
Onda-Cryl & $18.53 \pm 0.32 \mathrm{c}, \mathrm{A}$ & $12.01 \pm 0.44 \mathrm{a}, \mathrm{B}$
\end{tabular}

Means followed by the same lowercase letters in columns and uppercase letters in rows do not differ statistically by Tukey's test at $5 \%$.
$\mathrm{IS}=$ impact strength $\left(\mathrm{kgf} / \mathrm{cm}^{2}\right) ; \mathrm{I}=$ impact work accomplished $(\mathrm{kpcm}) ; \mathrm{L}=$ specimen width in the impact region $(\mathrm{cm})$; and $\mathrm{H}=$ specimen height in the impact region $(\mathrm{cm})$.

Specimens were submitted to 3-point bending test in an universal testing machine (Instron; Canton, MA, USA) running at a crosshead speed of $5 \mathrm{~mm} / \mathrm{min}$ until failure. Flexure value was obtained using the equation: $\mathrm{F}=3 \mathrm{WL} / 2 \mathrm{bd}^{2}$, where: $\mathrm{F}=$ flexure strength $\left(\mathrm{kgf} / \mathrm{cm}^{2}\right) ; \mathrm{W}=$ ultimate load before the failure; $\mathrm{L}=$ distance between the support points $(20 \mathrm{~mm}) ; \mathrm{b}=$ specimen width $(10 \mathrm{~mm}) ; \mathrm{d}=$ specimen thickness (3 $\mathrm{mm})$. Results were obtained in MPa by multiplying the values in $\mathrm{kgf} / \mathrm{cm}^{2}$ by the constant 0.098 .

Data from the non-disinfected and microwavedisinfected specimens were analyzed by ANOVA and Tukey's test at 5\% significance level, considering the acrylic resin and disinfection factors, as well as their interactions.

\section{RESULTS}

Table 1 shows that the KHN values of the acrylic resins presented statistically significant difference $(p<0.05)$ only in the non-disinfected specimens. Within the same acrylic resin, there was statistically significant difference $(\mathrm{p}<0.05)$ for Clássico and Onda-Cryl, with lower KHN values for the microwave-disinfected specimens.

There was no statistically significant difference (p>0.05) in the impact strength (Table 2) and flexural strength (Table 3 ) values of the acrylic resins in either non-disinfected or microwaved specimens. Within the

Table 2. Impact means $\left(\mathrm{kgf} / \mathrm{cm}^{2}\right)$ and standard deviations for Clássico, QC-20 and Onda-Cryl acrylic resins.

\begin{tabular}{ccc}
\hline Acrylic resin & \multicolumn{2}{c}{ Microwave disinfection } \\
\cline { 2 - 3 } & Non-disinfected & Disinfected \\
\hline Clássico & $7.25 \pm 1.91$ a,A & $7.66 \pm 0.81$ a,A \\
QC-20 & $8.19 \pm 0.55$ a,A & $8.59 \pm 0.49$ a,A \\
Onda-Cryl & $8.13 \pm 1.44$ a,A & $8.53 \pm 0.55$ a,A
\end{tabular}

Means followed by the same lowercase letters in columns and uppercase letters in rows do not differ statistically by Tukey's test at $5 \%$. 
same acrylic resin, no-disinfection and microwavedisinfection conditions showed no statistically significant difference $(p>0.05)$ for all materials.

\section{DISCUSSION}

Hardness test evaluates the material ability to withstand the indentation of a diamond indentor. An important clinical implication regarding hardness of acrylic resins is the possibility of abrasion over time during denture use (11). In the present study, when Knoop hardness was analyzed under no-disinfection and microwave-disinfection conditions (Table 1), the KHN values obtained for Clássico, QC-20 and OndaCryl acrylic resins differed significantly from each other. Although some authors have stated that hardness is not influenced by the acrylic resin type $(12,13)$, in the present study Onda-Cryl presented the highest hardness, followed by Clássico and QC-20.

A previous study (14) has shown that acrylic resins polymerized by microwave energy presents higher hardness when compared to those developed for conventional and fast cycles. This fact is attributed to differences in the residual monomer levels due to the distinct polymerization cycles, considering that the hardness should establish an inversely proportional relationship with the amount of residual monomer (15).

Although the acrylic resins evaluated in this study have similar chemical composition, the degree of conversion to change monomer into polymer is probably different for each material. Even though larger polymerization cycles promote smaller residual monomer levels (16), a previous study (17) showed that Knoop hard-

Table 3. Flexural strength means (MPa) and standard deviations for Clássico, QC-20 and Onda-Cryl acrylic resins.

\begin{tabular}{ccc}
\hline Acrylic resin & \multicolumn{2}{c}{ Microwave disinfection } \\
\cline { 2 - 3 } & Non-disinfected & Disinfected \\
\hline Clássico & $5.96 \pm 0.27$ a,A & $5.88 \pm 0.08$ a,A \\
QC-20 & $5.96 \pm 0.26$ a,A & $5.92 \pm 0.29$ a,A \\
Onda-Cryl & $6.12 \pm 0.49$ a,A & $6.28 \pm 0.32$ a,A
\end{tabular}

Means followed by the same lowercase letters in columns and uppercase letters in rows do not differ statistically by Tukey's test at $5 \%$ ness obtained with a conventional acrylic resin did not differ significantly from that obtained with an acrylic resin polymerized by microwave energy. In the present study; however, when the hardness was evaluated considering only the material, there was no statistically significant difference among the specimens submitted to microwave disinfection. Thus, it may be speculated that microwave disinfection produced a plasticizing effect on polymeric chains, promoting similar hardness for all materials.

Comparing non-disinfected and microwave-disinfected specimens, there was significant difference between Clássico and Onda-Cryl, both presenting lower hardness when microwaving was performed as a disinfection protocol. The decrease in hardness obsered in the microwaved acrylic resin specimens was likely due to the disarrangement of the resin polymeric chains, under the action of microwave energy. QC-20 resin has components for chemical activation in addition to the thermal activation, which could have accounted for the lack of significant difference between non-disinfected and disinfected specimens.

Impact tests provides relevant data for the study of fracture strength of the complete dentures fabricated with different types of acrylic resin materials. In the present study, there was not statistically significant difference in the impact strength values obtained for the acrylic resin specimens either disinfected or not (Table 2). The results obtained for the non-disinfected specimens were similar to those reported in a previous investigation with only non-disinfected specimens (14).

The basic chemical composition of the studied resins is poly (methyl methacrylate) with monomeric reinforcement to permit the arrangement in polymer cross-linkage (18). It is assumed that the energy absorbed during the impact suffered by the tested materials was similar, probably due to the similar values of resilience, which produced statistically similar fracture strength values, even after microwave disinfection.

Under the tested conditions, it was not confirmed that the acrylic resins polymerized by large cycle have better characteristics for energy absorption, due to long chains of high-molecular-weight polymers, in comparison to polymerization by microwave energy, with short chains of low-molecular-weight polymers (19). It was not confirmed either whether microwave-polymerized acrylic resins has a slightly better performance than the conventional resins, as reported elsewhere $(13,14)$. 
There was no remarkable difference in the flexural strength of the non-disinfected and microwavedisinfected specimens, when only the materials were compared (Table 3).

Flexural strength of complete denture bases in previous work (19) showed statistically significant difference among the acrylic resin types, although the microwave-polymerized resin did not absorb much more energy before failure in comparison to the water bath-polymerized acrylic resin. In the present study, microwave disinfection did not alter the level of absorbed energy during the flexural strength test for the nondisinfected procedure, maintaining similar values for all acrylic resins studied.

Although attempts were made to characterize the effect of microwave irradiation on the studied physical and mechanical properties, this investigation was limited to predicting the effect of other variables. Further research is necessary to evaluate whether the effect of repeated microwave disinfection may be deleterious to these properties of the acrylic resins. Although repeated microwave disinfections has been shown to decrease the internal adaptation of the denture base when compared to chemical disinfection (20), and microwave disinfection has been proven to have no significant effect on the base adaptation when the RS flask closure system was considered (10), future studies should compare the effect of other variables, like material investment, polymerization cycles and flask closure methods on acrylic base distortion and denture stability in oral use.

Within the limitations of this in vitro study, the tested null hypothesis that microwave disinfection adversely affects the hardness, impact strength and flexural strength of the evaluated acrylic resins was partly accepted. The results showed that microwave disinfection may be deleterious to the physical properties of acrylic resins. Based on the results, the following conclusions may be drawn: 1. Hardness of the resins was different only for non-microwave-disinfected specimens. Clássico and Onda-Cryl resins showed lower hardness values after disinfection. 2. Impact strength values of the resins comparatively and within each material did not differ significantly in either nondisinfected or microwave-disinfected specimens. 3 . Flexural strength values of the resins comparatively and within did not differ significantly in either non-disinfected or microwave-disinfected specimens.

\section{RESUMO}

Este estudo verificou o efeito da desinfecção por microondas sobre a dureza, impacto e resistência à flexão das resinas acrílicas Clássico, Onda-Cryl e QC-20. Matrizes de alumínio foram incluídas em muflas metálica ou de plástico com gesso pedra tipo III, de acordo com a técnica de inclusão tradicional. A proporção polímero/monômero foi de acordo com as recomendações dos fabricantes. Depois da polimerização em água à temperatura de $74^{\circ} \mathrm{C}$ por $9 \mathrm{~h}$, água em ebulição por $20 \mathrm{~min}$ ou por energia de microondas a $900 \mathrm{~W}$ por $3 \mathrm{~min}$, os corpos-de-prova foram demuflados após esfriamento da mufla em temperatura ambiente e submetidos ao polimento convencional. Testes de dureza, impacto e resistência à flexão foram feitos nos corpos-de-prova submetidos ou não à desinfecção por microondas. Cada corpode-prova foi submetido individualmente à desinfecção por microondas em forno doméstico com $900 \mathrm{~W}$ de potência por 3 min, imersos em $150 \mathrm{~mL}$ de água destilada. O teste de dureza Knoop foi realizado com carga de 25 g por $10 \mathrm{~s}$, a de impacto pelo sistema Charpy com $40 \mathrm{kpcm}$ e o de flexão por três pontos com velocidade de $0,5 \mathrm{~mm} / \mathrm{min}$ até fratura. Os dados foram submetidos à análise de variância e ao teste de Tukey $(\alpha=0,05)$. A desinfecção simulada por microondas diminuiu a dureza Knoop das resinas Clássico e Onda-Cryl e não promoveu nenhum efeito nas resistências ao impacto e à flexão das resinas estudadas.

\section{ACKNOWLEDGEMENTS}

This study was supported by PIBIC/CNPq/UNICAMP, at the Dental School of Piracicaba.

\section{REFERENCES}

1. Powell GL, Runnells RD, Saxon BA, Whisenant BK. The presence and identification of organisms transmitted to dental laboratories. J Prosthet Dent 1990;64:235-237.

2. Kahn RC, Lancaster MV, Kate W. The microbiologic crosscontamination of dental prostheses. J Prosthet Dent 1982;47:556-559.

3. Brace ML, Plummer KD. Practical denture disinfection. J Prosthet Dent 1993;70:538-540.

4. Rohrer MD, Bulard RA. Microwave sterilization. J Am Dent Assoc 1985;110:194-198.

5. Baysan A, Whiley R, Wright PS. Use of microwave energy to disinfect a long-term soft lining material contaminated with Candida albicans or Staphylococcus aureus. J Prosthet Dent 1998;79:454-458.

6. Dixon DL, Cardenzana A, Drake D, Breeding LC, Walton S. Microwave disinfection of denture base materials colonized with Candida albicans. J Prosthet Dent 1999;81:207-214.

7. Polyzois GL, Zissis AJ, Yannikakis SA. The effect of glutaraldehyde and microwave disinfection on some properties of acrylic denture resin. Int J Prosthodont 1995;8:150-154.

8. Pavan S, Arioli Filho JN, Santos PH, Mollo FA Jr. Effect of microwave treatments on dimensional accuracy of maxillary acrylic resin denture base. Braz Dent J 2005;16:119-123.

9. International Organization for Standardization. ISO 1567: Dentistry: denture base polymers 1998; Geneve, Switzerland.

10. Consani RLX, Mesquita MF, Nobilo MAA, Henriques GEP. 
Influence of simulated microwave disinfection on complete denture base adaptation using different flask closure methods. J Prosthet Dent 2007;97:173-178.

11. Craig RG. Prosthetic applications of polymers. In: Restorative Dental Materials. Craig RG and Powers JM, Editors. 11th ed. St Louis: CV Mosby; 2002:635-682.

12. Ilbay SG, Guvener S, Alkumru HN. Processing dentures using microwave technique. J Oral Rehabil 1994;2:103-109.

13. Reitz PV, Sanders JL, Levin B. The curing of denture acrylic resins by microwave energy. Physical properties. Quintessence Int 1985;6:547-550.

14. Smith LT, Powers JM, Ladd D. Mechanical properties of new denture resins polymerizes by visible light, heat and microwave energy. Int J Prosthodont 1992;5:315-320.

15. Jagger RG. Effect of the curing cycles on some properties of a poly-methylmethacrylate denture base material. J Oral
Rehabil 1978;5:151-157.

16. Austin AT, Basker RM. The level of residual monomer in acrylic denture base materials with particular reference to a modified method of analysis. Br Dent J 1980;149:281-286.

17. Truong VT, Thomaz FGV. Comparison of denture acrylic resins cured by boiling water and microwave energy. Aust Dent J 1998;33:201-204.

18. Anusavise KJ. Phillips' science of dental materials. 11th. ed. Chicago: Elsevier; 2003. p. 679-713.

19. Hayden WJ. Flexural strength of microwave-cured denture baseplate. Gen Dent 1996;34:367-371.

20. Sartori EA, Schmidt CB, Walber LF, Shinkai RS. Effect of microwave disinfection on denture base adaptation and resin surface roughness. Braz Dent J 2006;17:195-200.

Accepted April 1, 2008 